\title{
EDUKASI PEMANFAATAN DAUN KELOR MENJADI OLAHAN PRODUK PANGAN UNTUK MENAMBAH NUTRISI
}

\author{
Nomi Noviani \\ Universitas Muslim Nusantara Al-Washliyah \\ mamaanggun943@gmail.com
}

\begin{abstract}
ABSTRAK
Daun kelor dapat dikonsumsi oleh manusia, namun belum banyak masyarakat Indonesia yang mengonsumsinya dikarenakan karakteristik daun kelor memiliki bau yang khas dan tidak disukai. Di daerah pedesaan, konsumsi daun kelor hanya sebatas pada olahan sayuran berkuah seperti sayur bening dan lalapan saja (Simbolon, 2008). Menurut Zakaria, et al. (2013), daun kelor tidak banyak diolah sebagai pangan fungsional. Oleh karena itu, perlu adanya inovasi dalam mengolah daun kelor menjadi suatu produk yang dapat diterima masyarakat agar kandungan nutrisi dalam daun kelor dapat dimanfaatkan oleh tubuh. Tujuan pengabdian ini adalah untuk memberi edukasi kepada masyarakat khususnya ibu Pkk atau ibu rumah tangga, dengan adanya edukasi ini diharapkan masyarakat akan lebih kreatif dalam mengolah suatu produk. Karena banyak produk pertanian yang tidak di olah dan di buang, padahal produk tersebut banyak manfaat dan nilai gizi. Untuk mendukung hal tersebut, masyarakat lebih di kenalkan dengan tanaman kelor, berupa media pengenalan. Hasil yang sudah dicapai dalam pengabdian ini adalah : Memberikan pembelajaran dan pendampingan dalam meningkatkan manajemen wirausaha Home Industri ibu rumah tangga di kelurahan sidodadi, Kecamatan medan timur Kota Medan Provinsi Sumatera Utara. Memberikan wacana dan penjelasan kepada ibu ibu selaku mitra dalam pengabdian ini bagaimana cara meningkatkan manajemen wirausaha melalui usaha olahan daun kelo. Kualitas produk, bagaimana membuat produk yang berkualitas, salah satu nya melalui tampilan kemasan yang cantik sehingga mampu menarik minat masyarakat dan menghasilkan makanan yang sehat. Pemasaran, membantu mitra kami dalam memasarkan/mengenalkan produknya untuk lebih dikenal lagi oleh masyarakat luas, selain masyarakat di lingkungan di desa pematang johar, dengan memanfaatkan media sosial yang ada. (WhatsApp, Line, BB, Facebook, instagram). Promosi dengan cara ini sangat mudah dan bisa dikendalikan langsung setiap saat oleh mitra, dengan adanya promosi ini sangat memudahkan mitra untuk menjual produknya, hanya dengan menggunakan handphone android masyarakat lebih mudah mendapatkan informasi tentang produk yang dipasarkan. Apalagi di masa pandemi ini pemasaran melalui internet sangat banyak di gunakan, sehingga solusi untuk memperoleh keuntungan lebih mudah dengan pemasaran online.
\end{abstract}

Kata Kunci : edukasi, Pemanfaatan daun kelor, olahan produk pangan.

\begin{abstract}
Moringa leaves can be consumed by humans, but not many Indonesians consume them because the characteristics of Moringa leaves have a distinctive odor and are not liked. In rural areas, consumption of Moringa leaves is limited to processed vegetables such as clear vegetables and fresh vegetables (Simbolon, 2008). According to Zakaria, et al. (2013), Moringa leaves are not widely processed as functional food. Therefore, there is a need for innovation in processing Moringa leaves into a product that can be accepted by the community so that the nutritional content in Moringa leaves can be utilized by the body. The purpose of this service is to provide education to the community, especially Pkks or housewives, with this education it is hoped that the community will be more creative in processing a product. Because many agricultural products are not processed and discarded, even though these products have many benefits and nutritional values. To support this, the community is more introduced to the Moringa plant, in the form of an introduction medium. The results that have been achieved in this service are: Providing learning and assistance in improving the management of housewives' Home Industry entrepreneurs in Sidodadi Village, Medan Timur District, Medan City, North Sumatra Province. Providing a discourse and explanation to mothers as partners in this service how to improve entrepreneurial management through the processing of kelo leaves. Product quality, how to make quality products, one of them is through a beautiful display of packaging so as to attract public interest and produce healthy food. Marketing, helping our partners in marketing / introducing their products to be better known by the wider community, in addition to the
\end{abstract}


people in the environment in Pematang Johar village, by utilizing existing social media. (WhatsApp, Line, BB, Facebook, Instagram). Promotion in this way is very easy and can be controlled directly at any time by partners, with this promotion it makes it very easy for partners to sell their products, only by using an android mobile the community will find it easier to get information about the products being marketed. Especially in this pandemic era, marketing via the internet is very widely used, so the solution to making profits is easier with online marketing.

Keywords: education, Utilization of Moringa leaves, processed food products.

\section{PENDAHULUAN}

\section{Analisis Situasi}

Kelurahan Sidodi terletak di jalan Madong Lubis terletak di Jalan garu II Kecamatan Medan Amplas Kota Medan Sumatera no. 10A. Sebelah Utara, berbatasan dengan kelurahan perintis kecamatan medan timur, sebelah selatan berbatasan dengan kelurahan pandau hilir kecamatan medan area, sebelah timur berbatasan dengan kelurahan sei kera hulu kecamatan medan perjuangan, sebelah barat berbatasan dengan kelurahan gang buntu kecamatan medan timur, luas dan batas wilayah kelurahan sidodadi lebih kurang $40 \mathrm{Ha}$.

Kegiatan yang dilaksanakan bagi warga di kelurahan sidodadi sangat beragam antara lain kegiatan gotong royong, sosialisasi dari berbagai mitra untuk pengembangan kewirausahaan masyarakat terutama ibu- ibu PKK yang selalu rutin melaksanakan kegiatan, begitu juga dengan kelompok ibu- ibu pengajian yang juga merangkap sebagai ibu ibu PKK. Kegiatan Pengabdian ini di laksanakan di kelurahan sidodadi kecamatan medan timur.

\section{Permasalahan Mitra}

Daun kelor dapat dikonsumsi oleh manusia, namun belum banyak masyarakat Indonesia yang mengonsumsinya dikarenakan karakteristik daun kelor memiliki bau yang khas dan tidak disukai. Di daerah pedesaan, konsumsi daun kelor hanya sebatas pada olahan sayuran berkuah seperti sayur bening dan lalapan saja (Simbolon, 2008). Menurut Zakaria, et al. (2013), daun kelor tidak banyak diolah sebagai pangan fungsional. Oleh karena itu, perlu adanya inovasi dalam mengolah daun kelor menjadi suatu produk yang dapat diterima masyarakat agar kandungan nutrisi dalam daun kelor dapat dimanfaatkan oleh tubuh. Salah satu manfaat yang dapat diambil dari pohon kelor terdapat pada daunnya . Hasil penelitian menyatakan bahwa daun kelor memiliki berbagai kandungan nutrisi yang bermanfaat. Kandungan yang paling diunggulkan pada tanaman ini yaitu protein, vitamin A $(\beta-$ karoten), dan zat besinya yang tinggi sehingga bagus untuk dikonsumsi dan dapat memenuhi kebutuhan gizi terutama pada kelompok rawan

Dari uraian diatas permasalahan yang di temukan adalah:

1. Bagaimana menciptakan suatu metode yang menarik dan kreatif untuk mengedukasi masyarakat terutama ibu rumah tangga?

2. Bagaimana mengedukasi ibu rumah tangga untuk mengenalkan teknikteknik diversifikasi tanaman kelor menjadi produk makanan yang di gemari anak-anak?

\section{METODE PELAKSANAAN}

Metode yang digunakan dalam kegiatan Pengabdian Kemitraan Masyarakat ini adalah Deskriftif kuantitatif dengan metode pengenalan dasar yaitu pengenalan terhadap tanaman kelor melalui video. Selain itu, Praktek terapan pengolahan produk dari tanaman kelor. Membuat metode-metode pembelajaran dengan menggunakan tanaman kelor sebagai objek hasil olahan makanan yang sehat dan bisa digemari anak-anak dan meningkatkan tumbuh kembang. 


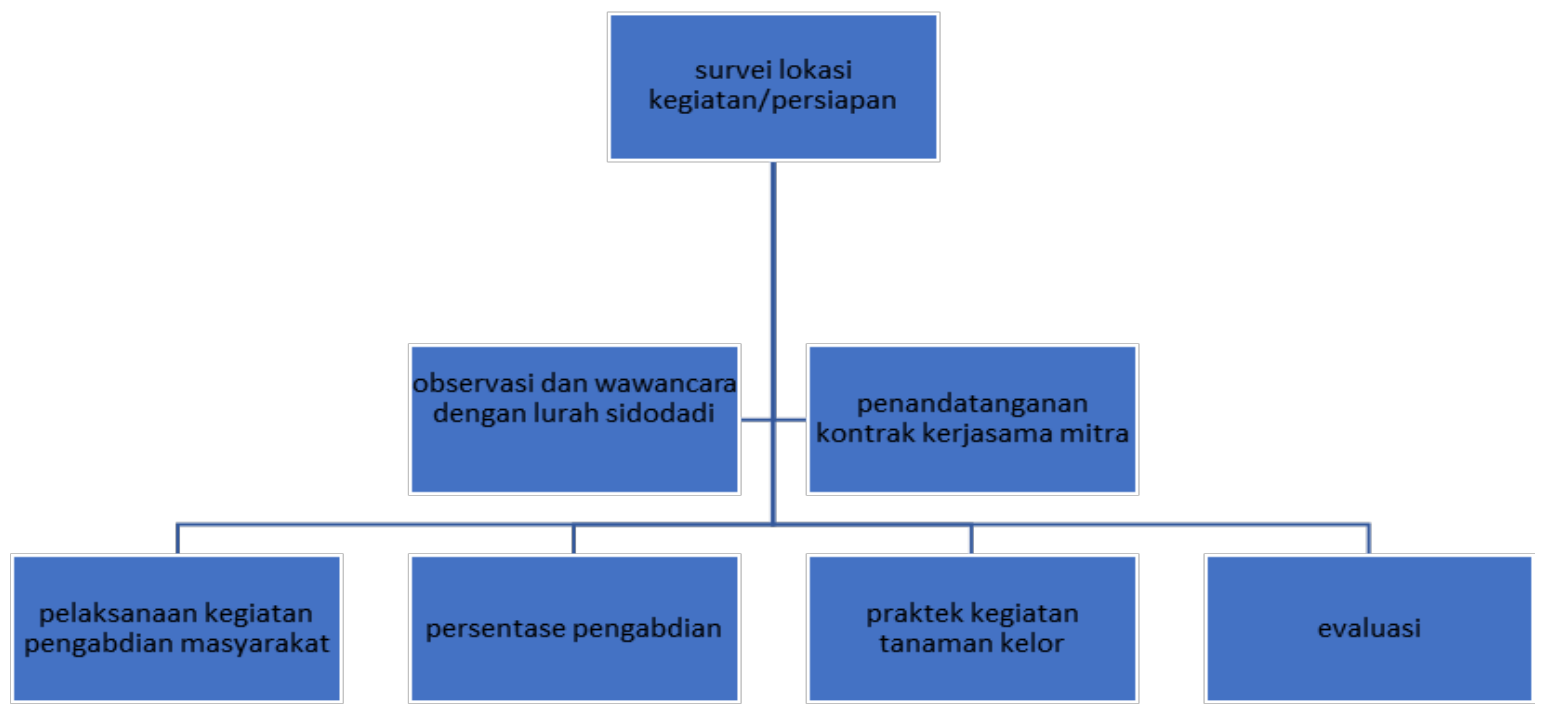

Gambar 1. Alur kegiatan Pengabdian

Masyarakat di Kelurahan Sidodadi

\section{HASIL DAN LUARAN YANG DICAPAI}

\subsection{Hasil Yang Dicapai}

Hasil yang sudah dicapai dalam pengabdian ini adalah :

1. Memberikan pembelajaran dan pendampingan dalam meningkatkan manajemen wirausaha Home Industri ibu rumah tangga di kelurahan sidodadi, Kecamatan medan timur Kota Medan Provinsi Sumatera Utara

2. Memberikan wacana dan penjelasan kepada ibu ibu selaku mitra dalam pengabdian ini bagaimana cara meningkatkan manajemen wirausaha melalui usaha olahan daun kelor.

3. Kualitas produk, bagaimana membuat produk yang berkualitas, salah satu nya melalui tampilan kemasan yang cantik sehingga mampu menarik minat masyarakat dan menghasilkan makanan yang sehat.

4. Pemasaran, membantu mitra kami dalam memasarkan/mengenalkan produknya untuk lebih dikenal lagi oleh masyarakat luas, selain masyarakat di lingkungan di desa pematang johar, dengan memanfaatkan media sosial yang ada.
(WhatsApp, Line, BB, Facebook, instagram). Promosi dengan cara ini sangat mudah dan bisa dikendalikan langsung setiap saat oleh mitra, dengan adanya promosi ini sangat memudahkan mitra untuk menjual produknya, hanya dengan menggunakan handphone android masyarakat lebih mudah mendapatkan informasi tentang produk yang dipasarkan. Apalagi di masa pandemi ini pemasaran melalui internet sangat banyak di gunakan, sehingga solusi untuk memperoleh keuntungan lebih mudah dengan pemasaran online.

\section{RENCANA TAHAPAN BERIKUTNYA}

Sebagaimana tercantum dari hasil dan luaran yang di capai dalam jangka panjang pengabdian ini bertujuan untuk mengembangkan memfocus pada penelitian dan pengembangan pemanfaatan daun kelor secara berkesinambungan sehingga banyak manfaat yang di peroleh masyarakat dari kegiatan pemanfaatan produk olahan dari daun kelor.

Pemanfaatan daun kelor merupakan bagian dari pengembangan, produk- produk olahan dari berbagai olahan yang bisa di manfaatkan menjadi produk olahan yang mempunyai nilai gizi yang tinggi dan mengandung manfaat kesehatan, dan 
mempunyai nilai tambah karena telah di olah menjadi produk pangan. belakangan ini banyak sekali hasil pertanian yang kaya manfaat dan kesehatan tidak banyak di manfaatkan hanya di buang begitu saja sebenarnya tanaman tersebut dapat di olah menjadi produk pangan yang mempunyai nilai jual.

Dengan telah diadakan pengabdian masyarakat yang berjudul Edukasi Pemanfaatan Daun Kelor Menjadi Olahan Produk Pangan Untuk Menambah Nutrisi. bisa memproduksi berbagai jenis olahan produk makanan dari daun kelor dan di pasarkan bukan hanya di daerah setempat tetapi dapat di pasarkan sampai keluar daerah sebagai produk unggulan suatu desa yang dapat menambah keterampilan dan ekonomi keluarga dengan membentuk home industri ibu PKK atau ibu rumah tangga di Kelurahan sidodadi Kecamatan Medan Timur Kota Medan.

\section{KESIMPULAN}

1. Pemanfaatan Daun kelor merupakan bagian dari pengembangan, produkproduk olahan yang bisa di manfaatkan menjadi produk olahan yang mempunyai nilai gizi yang tinggi, manfaat kesehatan dan mempunyai nilai tambah karena telah di olah menjadi produk pangan. Belakangan ini banyak sekali hasil pertanian yang hanya di buang begitu saja dan tidak di manfaatkan sebenarnya hasil pertanian tersebut dapat di olah menjadi produk pangan yang mempunyai nilai kesehatan dan gizi serta nilai jual.

2. Dari hasil pengabdian masyarakat yang telah dilaksanakan di Kelurahan Sidodadi, Kecamatan Medan Timur Kota Medan Provinsi Sumatera Utara. Masyarakat setempat sangat menerima terhadap pengenalan produk olahan dari daun kelor, dengan adanya olahan produk daun kelor masyarakat mendapatkan keterampilan baru dan bisa membuka suatu home industri yang bisa menghasilkan tambahan ekonomi keluarga sehingga pendapatan keluarga bisa meningkat

\section{SARAN}

Pemerintah harus ikut serta dalam kegiatan menghasilkan produk olahan daun kelor, dengan adanya kerjasama dengan pemerintah masyarakat tidak kesulitan untuk mendapatkan bantuan termasuk modal usaha dan pemasaran produk olahan.

\section{REFERENSI}

Nurmalinda et. al.: Persepsi Ibu Rumah Tangga terhadap Kelor dan Olahannya di DKI Jakarta. Buletin Pertanian Perkotaan Volume 10 Nomor 1, 2020. Balai Pengkajian Teknologi Pertanian Jakarta. Pusat Penelitian dan Pengembangan Tanaman Pangan, Jakarta Selatan

Susanty et. Al, Aktivitas Antioksidan Ekstrak Daun Kelor (Moringa Oleifera) Sebagai Zat Tambahan Pembuatan Moisturizer. P - ISSN : 2407 - 1846E - ISSN : 2460 - $8416 \quad$ Website : Jurnal.Umj.Ac.Id/Index.Ph $\mathrm{p} /$ Semnastek Seminar Nasional Sains Dan Teknologi 2019 Fakultas Teknik Universitas Muhammadiyah Jakarta.

Syarifah Aminah et.al.: Kandungan Nut risi dan Sifat Fungsional Tanaman Kelor ( $M$ oringa oleifera) Buletin Pertanian Perkotaan Volume 5 Nomor 2, 2015. Balai Pengkajian Teknologi Pertanian. Jakarta Selatan

Tri Budi Rahayu1 Et. Al. Kebidanan, Stikes Guna Bangsa 
Peningkatan Status Gizi

Balita Melalui Pemberian

Daun Kelor (Moringa

Oleifera). Jurnal Kesehatan

Madani Medika, Vol 9 No 2

Desember 2018 Issn (P) :

2088-2246 